\title{
Gastric Helicobacter-like Organisms in Stray Cats
}

\author{
S. D. ERGINSOY, M. SOZMEN \\ Department of Pathology, Faculty of Veterinary Medicine, \\ University of Kafkas, Kars, Turkey
}

Received May 25, 2005

Accepted March 16, 2006

\begin{abstract}
Erginsoy S. D., Sozmen M.: Gastric Helicobacter-like Organisms in Stray Cats. Acta Vet. Brno 2006: 75:91-98

Ten adult domestic shorthaired stray cats (Felis catus) were investigated for the presence and localization of different species of gastric Helicobacter-like organisms (GHLOs) using WarthinStarry silver staining, immunohistochemistry and transmission electron microscopy (TEM); the severity and distribution of lesions in different regions of the stomach were assessed in HE-stained sections. GHLOs were present in all areas of the stomach in all of 10 cats. Three morphologically different types of spiral-shaped bacteria were demonstrated; in silver-stained sections, $H$. pylori like organisms (HPLO) were easily differentiated from other GHLOs. Eight of the cats had $H$. heilmannii-like organisms (HHLOs) and one cat had HPLO. Mixed H. heilmannii and $H$. felis infection was seen in only one cat. GHLO infection was associated with a mild to severe gastritis in 8 of 10 cats. GHLOs colonized the cardia, corpus and antrum in similar density. The most striking histopathological changes consisted of accumulation of lymphocytes and neutrophilic granulocytes, fibrosis of the lamina propria mucosae, lymphoid follicles and lymphocytic infiltrates. There was no obvious relation between the degree of colonization by GHLOs and the extent of histopathological changes. GHLOs were present on the mucosal surface, in the lumen of gastric glands, and in the cytoplasm of parietal cells.

These findings indicate that immunohistochemistry and silver staining are useful for detecting GHLO infections, particularly with different Helicobacter species present. Stray cats are frequently colonized by HHLOs without any significant correlation between the degree of infection and gastritis score; in contrast HPLOs and HFLOs infections are not very common.
\end{abstract}

Feline, gastritis, helicobacter, immunohistochemistry, TEM

The presence of spiral bacteria in carnivorous pets has been known since the descriptions by Rappin (1881) and Bizzozero (1893), which were subsequently confirmed by Salomon (1898), all cited by Fox and Lee (1997). At present, more than 36 kinds of organisms with typical characteristics of Helicobacter spp. have been isolated from humans and different animals (Neiger 2001). H. felis was the first species isolated and identified from cat stomach (Lee et al. 1988) and subsequently H. heilmannii (formerly "Gastrosprillum hominis") (Heilmann and Borchard 1991), which is ultrastructurally indistinguishable from $H$. bizzozeronii (Hänninen et al. 1996). These two species are collectively referred to as gastric Helicobacter-like organisms (GHLOs) (Hänninen et al. 1996). H. heilmannii-like organisms (HHLOs) and $H$. felis are the Helicobacter species most commonly identified in the gastric mucosa of cats (Scanziani et al. 2001). These organisms can be differentiated based on bacterial morphology and location within the gastric mucosa (Utriainen et al. 1997).

Helicobacter pylori has been extensively studied since the discovery in humans it can be responsible for gastritis, peptic ulcers, gastric carcinoma and MALT-lymphoma (Chen et al. 2002). Some investigations have failed to isolate $H$. pylori from stray or pet cats (E1Zataari et al. 1997; Neiger et al. 1998). However, some other researchers revealed the presence of H. pylori in cat stomach (S canziani et al. 2001; S obhani et al. 2002) or saliva, gastric fluid and faeces (Fox et al. 1996) and it can promote gastritis when introduced into specific-pathogen-free cats (Fox et al. 1995a).

Address for correspondence:

Dr. Mahmut Sozmen

Department of Pathology, Faculty of Veterinary Medicine

University of Kafkas, 36100 Kars, Turkey
Phone: +90 474 2426801-ext: 1202

Fax: +90 4742426853

E-mail: msozmen@hotmail.com

http://www.vfu.cz/acta-vet/actavet.htm 
The detection of cat GHLO's in the human stomach has prompted several investigators to propose that feline Helicobacters may be transmitted to humans (Handt et al. 1994; F ox et al. 1996). Finally the detection of $H$. pylori in cats suggested a zoonotic risk with transmission occurring from cats to humans (Neiger and Simps on 2000). However, some investigations have failed to detect $H$. pylori in stray cats in Houston, Texas and they pointed the possibility of the anthroponositic potential of the disease (El-Zaatari et al. 1997).

Unlike H. pylori, "H. heilmannii" can naturally infect a broad range of animals, including cats, dogs, and primates, leading to mild and moderate gastritis (Eaton et al. 1996). Although high prevalence of $H$. heilmannii in pets is reported (Hermanns et al. 1995), in humans its absolute prevalence is very low, about 300 times lower than that of $H$. pylori (Morgner et al. 1995). It has been suggested to be an example of zoonosis (Stolte et al. 1994).

Despite the frequent occurrence of gastric bacteria in cats (Happonen et al. 1996b) there have been few studies examining the prevalence of these bacteria in different populations of animals, evaluating any gastric lesions associated with disease course and their presence (Neiger et al. 1998). The purpose of this study was to assess the prevalence and morphologic types of gastric bacteria and to determine if naturally occurring gastric bacteria were associated with gastritis in stray cats.

\section{Materials and Methods}

Animals

Ten adult domestic shorthaired stray cats (Felis catus) ( 4 male and 6 female) scheduled to be killed by the Kars City Municipality, Animal Control Center were studied. They were in good condition with no obvious signs of alimentary tract and other disease. All ten cats were euthanised with an intracardiac injection of pentobarbital sodium and necropsied systematically.

Gross pathology and histology

Gross lesions were recorded and samples were collected for histopathological and electron microscopical examinations. Gastric tissues taken from cardia, corpus and pyloric antrum were fixed in 10\% neutral buffered formalin and embedded in paraffin wax. Sections $(5 \mu \mathrm{m})$ were stained with hematoxylin-eosin (HE) for histopathological evaluation and with Warthin-Starry silver stain for identification and localization of the bacteria.

Quantitative assessment of histopathological findings

HE-stained sections of each stomach region were scored in a blinded fashion for lesion severity and distribution. For the histopathological assessment the presence of lymphocyte aggregates, the number of leukocytes, and the degree of GHLO colonization were recorded.

Grading of leucocytic infiltration was as follows for inflammatory cells (mean of three fields at 400$)$, ,-“ $(<5$; normal), ,+“ (5 to 25; mild), ,,++“(26-50; moderate), or , $+++“$ ( $>50$ severe). Lymphoid follicles were evaluated as atrophic, quiescent, or active, and densities per region were given intensity scores on a 3- $(+)$ scale for the cardia, corpus and pyloric antrum. ,-“ no lymphoid follicles per low-power field, ,,+“ fewer than two follicles per lowpower field, ,,+" greater than two follicles per low-power field, ,,++" greater than five follicles per low power field. The low power field had a total magnification of $20 \times$. The type and location of inflammatory cells per lowpower field were noted, as were spiral organisms. Products of intensity and distribution scores were calculated for determination of the lesion score.

Bacterial density was scored on a 3-(+) scale for the cardia, corpus and pyloric antrum as follows (mean of three fields at 400): ,,-" no bacteria, ,, + " (1 to 10; rare bacteria), ,,++" $(11-25$; bacteria in most or all fields $),,,+++"(>25$; bacteria densely packed in glands in most or all fields).

Gastritis was defined as follows: (-) ,no gastritis," no lymphoid aggregates, $<5$ leukocytes per high power field, and normal mucosal epithelium; $(+)$,mild gastritis, “ fewer than two lymphoid aggregates per low-power field and/or 5 to 25 leukocytes per high-power field and normal mucosal epithelium; $(++)$,,moderate gastritis," more than two lymphoid aggregates per low-power field, and 26 to 50 or more leukocytes per high-power field, and/or mild gastric epithelial changes; $(+++)$,,severe gastritis“, greater than five lymphoid aggregates and/or $>50$ leukocytes per high-power field and marked epithelial changes. Gastritis and density of bacterial colonization were scored separately for the cardia, corpus and pyloric antrum.

\section{Immunohistochemistry}

Sections from all tissue samples were also processed for immunohistochemical examination by a streptavidinbiotin-peroxidase method, with diaminobenzidine (Sigma, St. Louis, MO) as the chromogen. A primary rabbit polyclonal antibody against H. pylori (Dako ${ }^{\circledR}$ Diagnostica GmbH, Hamburg) was used at a 1/150 dilution. Nonimmune rabbit serum was used as a negative control. 
Transmission electron microscopy (TEM)

Gastric mucosa samples from two cases fixed in formalin were postfixed in 1\% osmium tetroxide, dehydrated, infiltrated, and embedded in Epoxy resin. Thick sections cut at $1 \mu \mathrm{m}$ were stained with toluidine blue (containing $1 \%$ borax). Thin sections, approximately $100 \mathrm{~nm}$ thick, were stained with uranyl acetate and lead citrate and examined at $80 \mathrm{kV}$ with a Philips 201 transmission electron microscope.

\section{Results}

Histological examination

Seven cats had mild to moderate inflammation in one or more regions of the stomach (Table 1). Inflammatory cells consisted of lymphocytes and occasional eosinophils and plasma cells. Another cat (No. 10) had severe gastritis characterised by infiltration of neutrophils and some lymphocytes and severe epithelial changes including cytoplasmic basophilia, fibrosis of the mucosa, and dilatation of the glands. Lymphoid follicle formation occurred in only 4 cats and was most prominent in the antrum. The two remaining cats were free of lesions in the stomach. No gastric erosions or ulcerations were observed in any of the cases.

Table 1. Semiquantitative analysis of gastric Helicobacter spp. positive cases ${ }^{a}$

\begin{tabular}{|cccccccccccccccc|}
\hline $\begin{array}{l}\text { Cat } \\
\text { No. }\end{array}$ & \multicolumn{3}{c}{$\begin{array}{c}\text { Organism } \\
\text { detected }\end{array}$} & \multicolumn{4}{c}{$\begin{array}{c}\text { Colonization } \\
\text { density }\end{array}$} & \multicolumn{3}{c}{$\begin{array}{c}\text { Leucocytic } \\
\text { infiltration }\end{array}$} & \multicolumn{3}{c|}{$\begin{array}{c}\text { Average No. of lymphoid } \\
\text { follicles/section }\end{array}$} & \multicolumn{3}{c|}{$\begin{array}{c}\text { Gastritis } \\
\text { score }\end{array}$} \\
\hline & HFLO $^{b}$ & HPLO & HHLO & C & Cp & A & C & Cp & A & C & Cp & A & C & Cp & A \\
\hline 1 & - & - & + & + & + & + & + & - & - & + & - & - & + & - & - \\
2 & - & - & + & +++ & ++ & ++ & - & - & - & - & - & - & - & - & - \\
3 & - & - & + & +++ & +++ & +++ & - & - & + & - & - & - & - & - & + \\
4 & - & - & + & +++ & +++ & ++ & - & ++ & - & - & + & - & - & ++ & - \\
5 & - & - & + & ++ & +++ & +++ & - & - & - & - & - & - & - & - & - \\
6 & + & + & - & +++ & +++ & +++ & - & - & ++ & - & - & ++ & - & - & ++ \\
7 & - & - & + & +++ & +++ & +++ & + & + & + & - & - & - & + & + & + \\
8 & - & - & + & ++ & ++ & ++ & + & + & + & - & - & - & + & + & + \\
9 & - & - & + & ++ & ++ & ++ & ++ & ++ & ++ & + & - & - & ++ & ++ & ++ \\
10 & - & - & + & +++ & +++ & +++ & +++ & +++ & +++ & - & - & - & +++ & +++ & +++ \\
\hline
\end{tabular}

a) Scoring was performed as described in Materials and Methods;

b) H. felis-like organism; c) H. pylori-like organism, d) H. heilmannii-like organism;

e) C: Cardia; Cp: Corpus; A: Antrum

\section{Prevalence and distribution of bacteria}

Warthin-Starry and immunostaining revealed gastric bacteria in all of the cats. In all the cases, the organisms were found to be single or in groups. Labelling ranged from diffuse to focal with most samples demonstrating positive organisms in the surface mucus covering the gastric epithelium. Microorganisms were located in the surface mucus, gastric pits, gastric glands in cardia, corpus, and pyloric region of the stomach (Table 1). These organisms were distributed over the entire mucosa. The gastric colonization appeared to be heaviest in the gastric pits and in the lumen of the gastric glands. Six of the infected cats were more heavily colonized than were the others.

Microscopic examination revealed three morphologic types of spiral bacteria. The first type was found in nine out of 10 cats. They were long and tightly coiled spiral organisms. These bacteria most resembled $H$. heilmannii (Plate IV, Fig. 1). On TEM examination, they were seen as tightly coiled seven to nine spirals with a gap of $0.8-1.0 \mu \mathrm{m}$ between each parallel strand, with an average length of $8 \mu \mathrm{m}$ in the sections (Plate IV, Fig. 2). Their diameter was between 0.5 and $1 \mu \mathrm{m}$. Periplasmic fibrils were not observed. Based on these morphological characteristics, the microorganisms were identified as $H$. heilmannii. 
The second type of bacteria was found in only one cat. They were present in the mucous layer, generally in close proximity to the gastric mucosal epithelial cells, in the lumina of the gastric pits and in the gastric glandular lumens (Plate V, Fig. 3). TEM revealed, within glandular lumina, short, slightly curved form of bacteria, approximately 2.5 to $4 \mu \mathrm{m}$ in length and 0.5 to $0.7 \mu \mathrm{m}$ in width (Plate V, Fig. 4). Some of bacteria were in intimate contact with epithelial cells. In morphology and location, these organisms were very similar to H. pylori of man. Bacteria were not observed intracellularly. These organisms were seen in all gastric regions examined.

The third type was found in only one case together with $H$. pylori-like bacteria. Organisms were seen as 5-9 $\mu \mathrm{m}$ long, loosely coiled spirals with 6-8 turns. These bacteria most resembled $H$. felis.

Eight cats had gastritis scores of ,,+“, ,++“" or ,,+++“ and corresponding bacterial scores of ,,+“, ,++" or ,,+++"; 2 cats had no gastritis in spite of large numbers of bacteria. The gastritis scores did not greatly differ among the cardia, corpus and pyloric antrum. Finally, there was no correlation between the presence or density of bacteria and the presence of mucosal lymphoid follicles and gastritis score.

\section{Discussion}

The widespread infection in the stomach of cats in the present study is similar to that reported in humans (Genta et al. 1993) and cats (Fox et al. 1996). The high prevalence of GHLO in cats is also reported in other published studies ranged from $41 \%$ to $100 \%$ (Happonen et al. 1996b; Papasouliotis et al. 1997).

Information regarding the frequency of different Helicobacter spp. in the cat stomach is scarce. H. felis, H. heilmannii, H. pylori were cultured from cat stomach (Neiger at al. 1998; Simps on et al. 2001). Among these species, H. felis-like bacteria were found in only one cat mixed with HHLO. In the present study, H. pylori-like bacteria were found in one cat. The rare detection of $H$. pylori in cats, particularly in specific-pathogen free laboratory cats (Handt et al. 1994) with absence of $H$. felis or H. heilmannii was attributed to the lack of normal gastric flora and they became colonized by contact with a human caretaker (Eat on et al. 1996). Several studies have pointed that having cats is not associated with an increased potential risk of acquiring H. pylori infection (Ansorg et al. 1995; Webb et al. 1996). However, in cats with naturally acquired gastric $H$. pylori colonization similar to those infected people were also known (Scanziani et al 2001; Simpson et al. 2001).

In the present study, the intensity of the gastric bacterial colonization of stray cats was not different from other studies where pet cats were studied (Scanziani et al. 2001; Sobhani et al. 2002). While some studies (Ot to et al. 1994) found a correlation between age and the presence of GHLO, others (Esteves et al. 2000; Neiger et al. 1998) did not find more spiral organisms in older cats. Otto et al. (1994) reported an increase of lymphoid follicles in older cats with high numbers of GHLO in the gastric mucosa versus younger cats with lower indices of GHLO colonization in pound-source cats. In the present study, HHLOs were detected in the majority of the cases, which is responsible for causing chronic gastritis in cats (Feinstein and Olss on 1992). Zoonotic potential of gastric spiral organisms other than H. pylori has been reported (Stolte et al. 1994; Dietrich et al. 1998). On the other hand concomitant infections by $H$. heilmannii and $H$. pylori were very rare and attributed as a result of competitive exclusion of $H$. heilmannii from infection with $H$. pylori (Stolte et al. 1994).

In the present study, both impregnation and immunohistochemistry indicated that the cardia, corpus, and pyloric antrum are almost equally colonized. However, some studies (Happonen et al. 1996a, 1996b) showed that cardia and corpus an area rich in parietal cells, of the stomach were more heavily and often colonized than the antrum in cats infected with 
$H$. felis and H. heilmannii. Different patterns of colonization were reported in BALB/c mice infected with $H$. felis where localization observed in cardia and antrum because of the various gastric $\mathrm{pHs}$ of the different stomach regions (D a n on et al. 1995). This suggests that host-specific factors are involved, and one possible mechanism that has been described is the ability of some Helicobacters to inhibit the secretory function of parietal cells directly (Vargas et al. 1991).

In the present study, mild chronic gastric lesions were found in HPLO and HHLOsinfected cats. The lesions consisted mainly of lymphocytic infiltrates and some mucosal lymphocytic aggregates at least in one region of the stomach in 4 of 10 cats. The mild chronic gastritis noted in $H$. pylori-infected cat was similar to that observed in cats colonized by HHLOs. HHLO infection was associated with mild or moderate chronic active gastritis characterized by lymphocytic infiltrates in the superficial mucosa as well as neutrophils in two cats. However, marked chronic active gastritis associated with glandular atrophy and fibrosis with neutrophilic infiltration was detected in only one cat. In most cases, the inflammatory infiltrate was not accompanied by epithelial changes. There was no relation between Helicobacter colonization density and the severity of mucosal inflammation or the number of lymphoid follicles observed as in other studies (Happonen et al. 1998). Most cats had many bacteria and only signs of mild gastritis. Similar pattern of gastritis previously described in natural or experimental Helicobacter infection in cats (Otto et al. 1994; Fox et al. 1996). However, in contrast to cats, human gastric mucosa is often infiltrated by neutrophils and exhibits glandular microabscesses (Genta et al. 1993). Hermanns et al. (1995) reported histopathological changes in cats with signs of vomiting and diarrhoea including glandular degeneration with accumulation of lymphocytes and neutrophils, fibrosis and oedema of the lamina propria and presence of lymphoid follicles, which is correlated with the degree of GHLO colonisation. On the other hand some researchers reported inflammatory changes including oedema and lymphoplasmacytic infiltration of the lamina propria in both cats with GHLOs and without bacterial association (Geyer et al. 1993; Neiger et al. 1998). Whereas Papasouliotis et al. (1997) reported no histopathological abnormalities in any of the cats either with or without clinical signs.

The presence of lymphoid aggregates has long time been considered a non-specific histological finding in the gastric mucosal architecture of cats (A d a m et al. 1970). However, it was shown absence of lymphoid aggregates in the cats free of gastric organisms (Handt et al. 1995). In contrast, cats harbouring $H$. pylori, GHLOs and H. felis developed large numbers of lymphoid follicles (Handt et al. 1995). In the present study, H. pylori-infected cat had more numerous lymphoid aggregates than that of $H$. heilmannii-infected cats. Multiple lymphoid follicles have also been described in H. pylori infected humans (Zerbib and Vialette 1994), and cats (Scanziani et al. 2001). However, H. heilmannii is common in pet cats, and it is generally associated with minimal inflammation (Norris et al. 1999) as in present study. H. pylori and GHLOs are known to be involved in ulcerogenesis in humans and ferrets (Fox et al. 1991). Gastric ulcers were not seen in the cats we examined and in other studies (Handt et al. 1994; Otto et al. 1994). These findings show that different Helicobacter species cause differences in the severity of gastritis in infected cats as it shown by others (Nieger and Simpson 2000; Scaznziani et al. 2001).

The route of transmission for members of the genus Helicobacter is much of debate. Isolation of $H$. pylori from human and cat dental plaques, saliva, and feces (Kelly et al. 1994; F ox et al. 1996) prompted some authors (Fox et al. 1996) to propose oral-oral and faecal-oral route of transmission. Oral-oral transmission of $H$. heilmannii was suggested as a result of exposure to companion animals (Lavelle et al. 1994). Considering long in vitro survival of gastric Helicobacters in the stomach contents of cats (Fox et al. 1995b) and eliminating these bacteria alive in their saliva by vomiting, grooming and licking, consequently contact with 
them could be source of human infection. Frequent occurrence of GHLO in the cats increases possibility of risk of transmission to human patients despite low prevalence of $H$. heilmannii in human patients (Svec et al. 2000). Furthermore, the detection of H. pylori in the stray cats could indicate that cats could be a potential reservoir for the bacterium (Handt et al. 1994). In the present study, the low occurrence of $H$. pylori in stray cats contrasts with the other studies and reports where no HPLO were detected in stray cats (E1-Zaatari et al. 1997; Neiger 2001). The presence of $H$. pylori in stray cats raises the question of possible source infection. The presence and resistance for 40 hours in water suggest that there may be environmental reservoir of $H$. pylori (Klein et al. 1991). Transmission of $H$. pylori has generally been considered to be oral-oral as well as faecal-oral route (Fox et al. 1996) presuming the reservoir of the organism is pet cats, humans or large animals for slaughter (Dimola and Caruso 1999). For that reason, the actual frequency of $H$. pylori infection in pet cats has should been determined in order to reveal the differences between stray and pet cats.

In conclusion, stray cats are frequently colonized by GHLOs without any significant correlation between the degree of infection and gastritis score.

\section{Helikobakteru podobné organismy v žaludku toulavých koček}

Deset toulavých krátkosrstých koček domácích (Felis catus) bylo vyšetřováno s využitím Warthin-Starryova barvení stříbrem, imunohistochemie a transmisivní elektronové mikroskopie (TEM) na přítomnost a lokalizaci různých druhů heliokobakteru podobných organismů v žaludku (GHLO). Vážnost a distribuce/rozšíření lézí v různých částech žaludku byly hodnoceny na řezech barvených HE (hematoxylin eosin). GHLO se vyskytovaly ve všech částech žaludku u všech deseti koček. Byly pozorovány 3 morfologicky odlišné typy spirálovitých bakterií. Organismy podobné $H$. pylori (HPLO) byly ve stř́ibrem barvených řezech od ostatních GHLO snadno rozlišitelné. U osmi koček byly zjištěny $H$. heilmannii podobné organismy (HHLO) a u jedné HPLO. Smíšená infekce $H$. heilmannii a $H$. felis byla zjištěna pouze u jediné kočky. U osmi z deseti koček byla infekce GHLO spojena s lehkou až těžkou gastritidou. GHLO kolonizovaly stejně kardii, fundus i antrum pylori. Nejnápadnějšími patohistologickými změnami byla akumulace lymfocytů a neutrofilních granulocytů, fibróza lamina propria mucosae, lymfoidní folikuly a infiltrace lymfocyty. Nebyl nalezen zřejmý vztah mezi stupněm kolonizace GHLO a rozsahem histopatologických změn. GHLO se nacházely na povrchu sliznice, v luminu žaludečních žlázek a v cytoplazmě parietálních buněk.

Tyto nálezy ukazují, že immunohistochemie a barvení stř́ibrem jsou vhodné pro detekci GHLO infekcí a to zejména v případech, kdy je přítomno více různých druhů Helicobacter. Žaludek toulavých koček je často kolonizován HHLO bez signifikantní korelace mezi stupněm infekce a vážností gastritidy. Naproti tomu HPLO a HFLO infekce nejsou velmi časté.

\section{Acknowledgements}

This study was supported by the Research Fund of Kafkas University, Turkey (Project No: 2000.VF.006). The authors thank Dr. Peter Brown, Comparative Pathology Laboratory, University of Bristol, Veterinary School, Langford, Bristol BS40 5DU, U. K. for his critical review of this manuscript.

\section{References}

ADAM WS, CALHOUN ML, SMITH EM, STINSON AW 1970: In: Microscopic anatomy of the dog: a photographic atlas, plate 63, Fig. 3b. Charles C. Thomas, Publisher, Springfield, III

ANSORG R, HEINTSCHEL van HEINEGG E, von RECKLINGHAUSEN G. 1995: Cat owners' risk of acquiring a Helicobacter pylori infection. Zentralbl Bakteriol 283: 122-126

CHEN XY, LIU WZ, SHI Y, ZHANG DZ, XIAO SD, TYTGAT GN 2002: Helicobacter pylori associated gastric diseases and lymphoid tissue hyperplasia in gastric antral mucosa. J Clin Pathol 55: 133-137 
DANON SJ, O'ROURKE JL, MOSS ND, LEE A 1995: The importance of local acid production in the distribution of Helicobacter felis in the mouse stomach. Gastroenterology 108: 1386-1395

DIETRICH C, WIESEL P, NEIGER R, BLUM A, CORTHESY-THEULAZ I 1998: Presence of multiple „Helicobacter heilmannii“" strains in an individual suffering from ulcers and in his two cats. J Clin Microbiol 36: 1366-1370

DIMOLA S, CARUSO ML 1999: Helicobacter pylori in animals affecting the human habitat through the food chain. Anticancer Res 19: 3889-3894

EATON KA, DEWHIRST FE, PASTER BJ, TZELLAS N, COLEMAN BE, PAOLA J, SHERDING R 1996: Prevalence and varieties of Helicobacter species in dogs from random sources and pet dogs: Animal and public health implications. J Clin Microbiol 34: 3165-3170

EL-ZAATARI FA, WOO JS, BADR A, OSATO MS, SERNA H, LICHTENBERGER LM, GENTA RM, GRAHAM DY 1997: Failure to isolate Helicobacter pylori from stray cats indicates that H. pylori in cats may be an anthroponosis-an animal infection with a human pathogen. J Med Microbiol 46: 372-376

ESTEVES MI, SCHRENZEL MD, MARINI RP, TAYLOR NS, XU S, HAGEN S, FENG Y, SHEN Z, FOX JG 2000: Helicobacter pylori gastritis in cats with long-term natural infection as a model of human disease. Am J Pathol 156: 709-721

FEINSTEIN RE, OLSSON E. 1992: Chronic gastroenterocolitis in nine cats. J Vet Diagn Invest 4: 293-298

FOX JG, LEE A 1997: The role of Helicobacter species in newly recognized gastrointestinal tract diseases of animals. Lab Anim Sci 47: 222-255

FOX JG, OTTO G, MURPHY JC, TAYLOR NS, LEE A 1991: Gastric colonization of the ferret with Helicobacter species: natural and experimental infections. Rev Infect Dis 13: 671-680.

FOX JG, BATCHELDER M, MARINI RP, YAN L, HANDT K, LI X, SHAMES B, HAYWARD A, CAMPBELL J, MURPHY JC 1995a: Helicobacter pylori induced gastritis in the domestic cat. Infect Immun 63: 2674-2681

FOX JG, PERKINS S, YAN L, TAYLOR N, ATTARDO L, PAPPO J 1995b: Public health implication of Helicobacter pylori in cat saliva, gastric juice and feces. Gut 37: 10-13

FOX JG, PERKINS S, YAN L, SHEN Z, ATTARDO L, PAPPO J 1996: Local immune response in Helicobacter pylori-infected cats and identification of $H$. pylori in saliva, gastric fluid and faeces. Immunology $\mathbf{8 8}$ : 400-406

GENTA RM, HAMNER HW, GRAHAM DY 1993: Gastric lymphoid follicles in Helicobacter pylori infection; frequency, distribution and response to triple therapy. Human Pathol 24: 577-583

GEYER C, COLBATZKY F, LECHNER J, HERMANNS W 1993: Occurrence of spiral shaped bacteria in gastric biopsies of dogs and cats. Vet. Rec. 133: 18-19

HANDT LK, FOX JG, DEWHIRST FE, FRASER GJ, PASTER BJ, YAN L, ROZMIAREK LH, RUFO R, STALIS IH 1994: Helicobacter pylori isolated from domestic cat: public health implications. Infect Immun 62: 2367-2374

HANDT LK, FOX JG, STALIS IH, RUFO R, LEE G, LINN J, LI X, KLEANTHOUS H 1995: Characterization of feline Helicobacter pylori strains and associated gastritis in a colony of domestic cats. J Clin Microbiol 33: 2280-2289

HÄNNINEN ML, HAPPONEN IH, SAARI S, JALAVA K 1996: Culture and characteristics of Helicobacter bizzozeronii, a new canine gastric Helicobacter sp. Int J Syst Bacteriol 46: 160-166

HAPPONEN I, SAARI S, CASTREN L, TYNI O, HÄNNINEN ML, WESTERMARCK E, 1996a: Occurrence and topographical mapping of gastric Helicobacter-like organisms and their association with histological changes in apparently healthy dogs and cats. Zentralbl Veterinarmed A 43: 305-315

HAPPONEN I, SAARI S, CASTREN L, TYNI O, HANNINEN ML, WESTERMARCK E 1996b: Comparison of diagnostic methods for detecting gastric Helicobacter-like organisms in dogs and cats. J Comp Pathol 115: $117-127$

HAPPONEN I, LINDEN J, SAARI S, KARJALAIENEN M, HANNINEN ML, JALAVA K, WESTERMARCK E 1998: Detection and effects of Helicobacters in healthy dogs and dogs with signs of gastritis. J Am Vet Med Assoc 213: 1767-1774

HEILMANN KL, BORCHARD F 1991: Gastritis due to spiral shaped bacteria other than Helicobacter pylori. Clinical, histological and ultrastructural findings. Gut 32: 137-140

HERMANNS W, KREGEL K, BREUER W, LECHNER J 1995: Helicobacter-like organisms: histopathological examination of gastric biopsies from dogs and cats. J Comp Pathol 112: 307-318

KELLY SM, PITCHER MCL, FARMERY SM, GIBSON GR 1994: Isolation of Helicobacter pylori from feces of patients with dyspepsia in the United Kingdom. Gastroenterology 107: 1671-1674

KLEIN PD, GRAHAM DY, GAILLOUR A, OPEKUN AR, O'BRIAN SMITH E 1991: Water source as risk factor for Helicobacter pylori infection in Peruvian children. Lancet 337: 1503-1506

LAVELLE JP, LANDAS S, MITROS FA, CONKLIN JL 1994: Acute gastritis associated with spiral organisms from cats. Dig Dis Sci 39: 744-750

LEE A, HAZELL SL, O'ROURKE J, KOUPRACH S 1988: Isolation of a spiral-shaped bacterium from the cat stomach. Infect Immun 56: 2843-2850

MORGNER A, BAYERDORFFER E, MEINING A, STOLTE M, KROHER G 1995: Helicobacter heilmannii and gastric cancer. Lancet 346: 511-512 
NEIGER R 2001: Helicobacter-gastritis in cats and dogs. Proceedings of the 7th European FECAVA \& 47 th FKDVG congress. Berlin, Germany. pp. 89-91

NEIGER R, SIMPSON KW 2000: Helicobacter infection in dogs and cats: facts and fiction. J Vet Intern Med 14: 125-133

NEIGER R, DIETERICH C, BURNENS A, WALDVOGEL A, CORTHÉSY-THEULAZ I, HALTER F, LAUTERBURG B, SCHMASSMANN A 1998: Detection and prevalence of Helicobacter infection in pet cats. J Clin Microbiol 36: 634-637

NORRIS CR, MARKS SL, EATON KA, TORABIAN SZ, MUNN RJ, SOLNICK JV. 1999. Healthy cats are commonly colonized with „Helicobacter heilmannii“ that is associated with minimal gastritis. J Clin Microbiol 37: 189-194

OTTO G, HAZELL S, FOX JG, HOWLETT CR, MURPHY JC, O’ROURKE JL, LEE A 1994: Animal and public health implications of gastric colonization of cats by Helicobacter like organisms. J Clin Microbiol 32: 1043-1049

PAPASOULIOTIS K, GRUFFYDD-JONES TJ, WERRET G, BROWN PJ, PEARSON GR 1997: Occurrence of gastric 'Helicobacter like organisms' in cats. Vet. Rec. 140: 369-370

SCANZIANI E, SIMPSON KW, MONESTIROLI S, SOLDATI S, STRAUSS-AYALI D, DEL PIERO F 2001: Histological and immunohistochemical detection of different Helicobacter species in the gastric mucosa of cats. J Vet Diagn Invest 13: 3-12

SIMPSON KW, STRAUSS-AYALI D, STRAUBINGER RK, SCANZIANI E, MCDONOUGH PL, STRAUBINGER AF, CHANG YF, ESTEVES MI, FOX JG, DOMENEGHINI C, AREBI N, CALAM J 2001: Helicobacter pylori infection in the cat: evaluation of gastric colonization, inflammation and function. Helicobacter 6: 1-14

SOBHANI I, CANEDO S, ALCHEPO B, V SSUZAINE C, CHEVALIER C, BUYSE M, MOIZO L, LAIGNEAU JP, MIGNON M, LEWIN JM, BADO A 2002: Putative effect of Helicobacter pylori and gastritis on gastric acid secretion in cat. Am J Physiol 282: G727-734

STOLTE M, WELLENS E, BETHKE B, RITTER M, EIDT H 1994: Helicobacter heilmannii (formerly Gastrospirillum hominis) gastritis an infection transmitted by animals? Scand J Gastroenterol 29:1061-1064

SVEC A, KORDAS P, PAVLIS Z, NOVOTNY J 2000: High prevalence of Helicobacter heilmannii-associated gastritis in a small, predominantly rural area: further evidence in support of a zoonosis? Scand J Gastroenterol 35: $925-928$

UTRIAINEN M, JALAVA K, SUKURA A, HÄNNINEN ML 1997: Morphological diversity of cultured canine gastric Helicobacter spp. Comp Immun Microbiol Infect Dis 20: 285-297

VARGAS MA, LEE A, FOX JG, CAVE DR 1991: Inhibition of acid secretion from parietal cells by non-humaninfecting Helicobacter species: a factor in colonization of gastric mucosa? Infect Immun 59: 3694-3699

WEBB PM, KNIGHT T, ELDER JB, NEWELL DG, FORMAN D 1996: Is Helicobacter pylori transmitted from cats to humans? Helicobacter 1: 79-81s

ZERBIB F, VIALETTE G 1994: Les gastrites folliculaires. Hepatogastroenterology 3: 189-192 
Plate IV

Erginsoy S. D. and Sozmen M.: Gastric Helicobacter ... pp. 91-98

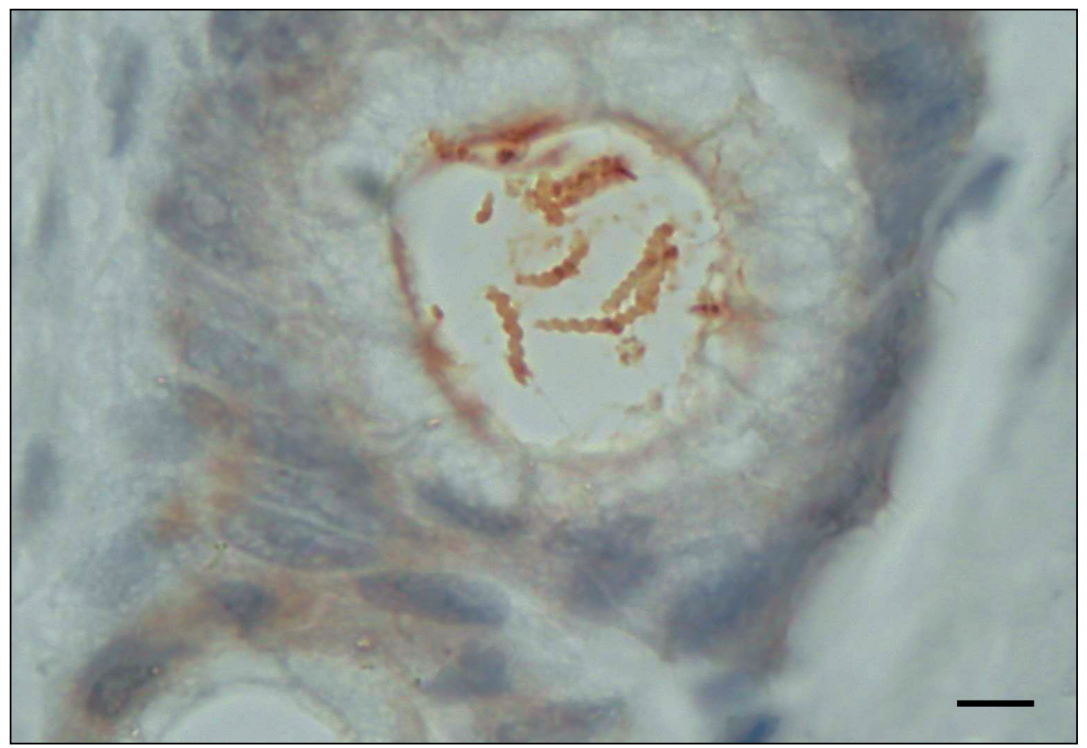

Fig. 1. Tight, helix-shaped $H$. heilmannii-like bacteria in the gastric glandular lumen. ABC, Bar $=10 \mu \mathrm{m}$.

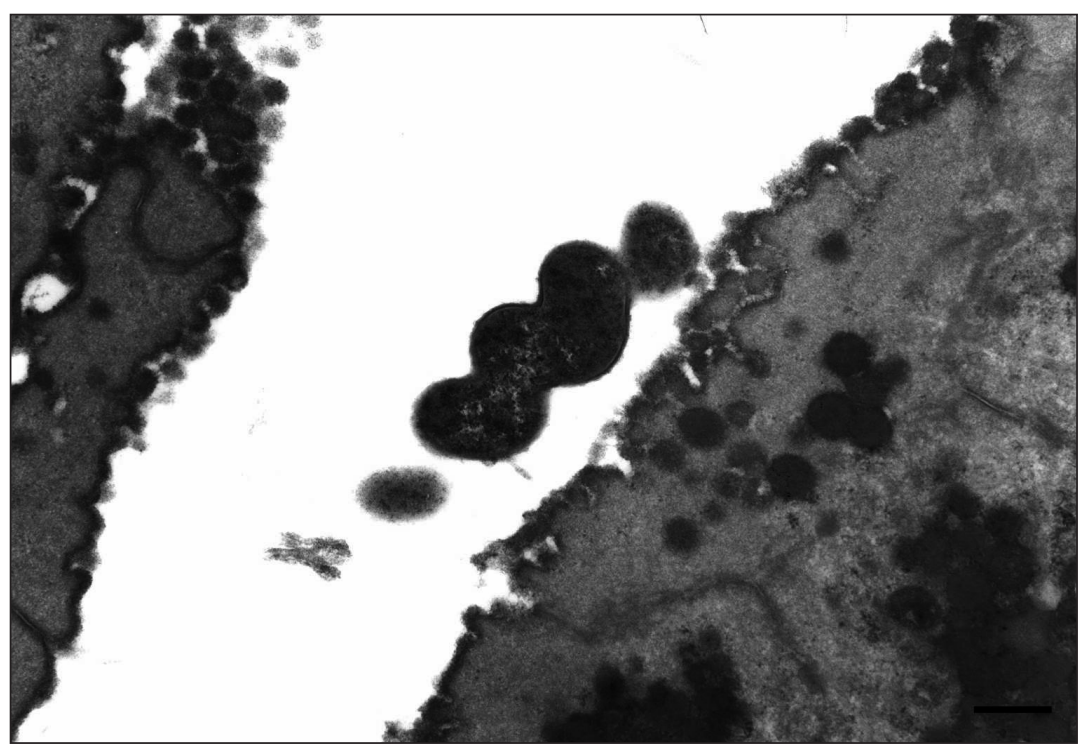

Fig. 2. Tight, helix-shaped bacteria without periplasmic fibrils resembling " $H$. heilmannil" in the lumen of a pyloric gland. TEM, Bar $=0,44 \mu \mathrm{m}$. 


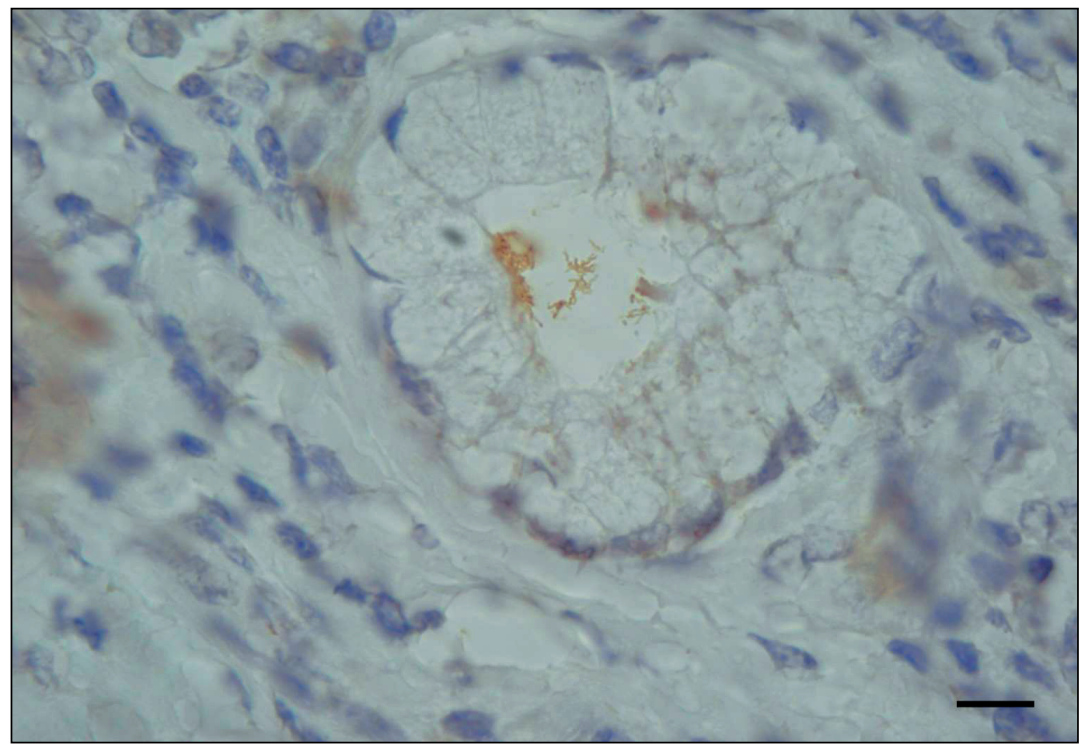

Fig. 3. Clusters of HPLOs in superficial gastric glandular lumen of a cat. $A B C ; B a r=10 \mu \mathrm{m}$.

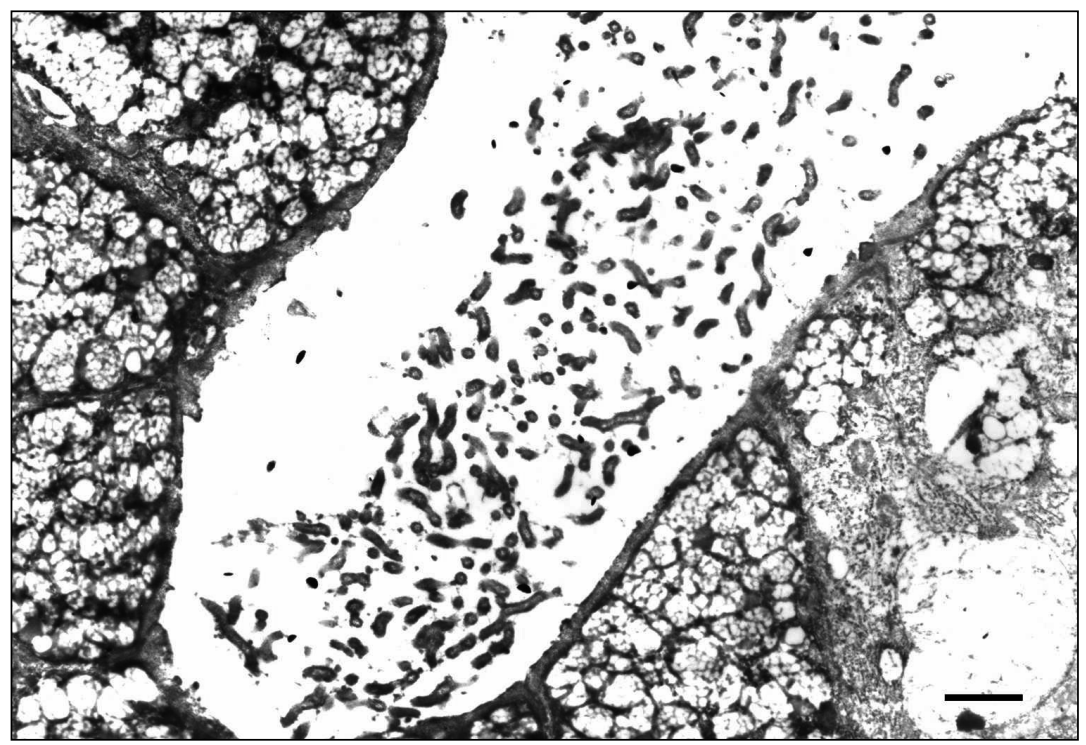

Fig. 4. TEM shows numerous HPLOs in the glandular lumen of an infected cat stomach. Bar $=2.22 \mu \mathrm{m}$. 